\title{
INJURY SURVEILLANCE IN THE PROFESSIONAL FOOTBALL CODES: AN OVERVIEW OF CURRENT DATA COLLECTION, INJURY DEFINITION AND REPORTING PRACTICES
}

Louise Shaw ${ }^{1}$, John Orchard ${ }^{2}$, Richard Saw ${ }^{3}$, Caroline F Finch ${ }^{1}$

${ }^{1}$ Australian Collaboration for Research into Injury in Sport and its Prevention, Federation University Australia, Ballarat, Victoria, Australia

${ }^{2}$ School of Public Health, University of Sydney, Sydney, Australia

${ }^{3}$ Olympic Park Sports Medicine Centre, Melbourne, Victoria, Australia

Corresponding author: Professor Caroline Finch, Australian Collaboration for Research into Injury in Sport and its Prevention (ACRISP), Federation University Australia, PO Box 663, Ballarat, Victoria, Australia, 3353, Email: c.finch@federation.edu.au. Phone: +61 409 186085. 
AUTHORS INFORMATION

Conflicts of Interest

John Orchard was the AFL injury surveillance coordinator from 1992-2014, inclusive.

\section{Funding}

Caroline Finch was supported, in part, by an NHMRC Principal Research Fellowship (ID: 1058737).

\section{Specific author contributions to this manuscript}

Louise Shaw undertook the conduct of the review; major writing role; the literature search and collation of evidence from the selected papers. John Orchard contributed to the initial paper design and concept; contributed to the writing; edited the manuscript versions. Richard Saw contributed to the writing; edited the manuscript versions. Caroline Finch contributed to the design of the study and its methodological conduct; assisted with interpretation of findings; contributed to the writing; edited the manuscript versions.

\section{Acknowledgements}

The Australian Centre for Research into Injury in Sport and its Prevention (ACRISP) is one of the International Research Centres for the Prevention of Injury and Protection of Athlete Health supported by the International Olympic Committee (IOC). 


\section{ABSTRACT}

INTRODUCTION:

Whilst football has been found to have many positive effects from a health perspective, injuries are common, particularly at the elite or professional level of play. Injury surveillance is therefore required to inform the development and implementation of strategies to increase safety in professional football codes.

\section{EVIDENCE ACQUISITION:}

A systematic search of peer reviewed and available grey literature was conducted to identify publications presenting methodological details of ongoing injury surveillance systems in professional football codes. Data extracted included population under surveillance, player/ team coverage, injury definition and other relevant information.

\section{EVIDENCE SYNTHESIS:}

Following literature search and review, seven injury surveillance systems were identified that record ongoing data within professional football codes. A range of methodologies was used across the surveillance systems with variations in the definitions of injury, who records the data, the data-recording tool and dissemination of the data.

\section{CONCLUSIONS:}

There are many benefits for football associations, clubs and players themselves in conducting comprehensive injury surveillance. A range of surveillance methods is employed across the different football codes including injury definition. Some professional football codes have developed consensus statements, which provide guidance on key issues relating to injury surveillance. Dissemination of findings differed with some systems publishing via peer review journals, with others through annual disclosure to the media. Financial considerations and funding are a crucial factor for creating and maintaining an injury surveillance system. Findings from football injury surveillance have been used to 
implement rule changes and develop preventive programmes, all aimed at increasing player safety.

\section{KEYWORDS}

Football; injury surveillance; consensus statements; injury definition 


\section{INTRODUCTION}

Football can be used as an encompassing term for a number of different types of sport (also sometimes referred to as "the football codes") that are characterised by running, ball kicking and other actions. The main types of football are soccer (also known as Association football in some parts of the world), American football (also known as Gridiron), Australian football (sometimes known as Australian rules football or professionally as Australian Football League $[A F L]$ football), Gaelic football, rugby league and rugby union. There are also some modified versions of some of these sports (e.g. Futsal, touch football). Internationally, soccer is the most common team participation sport. In 2006, the Federation Internationale de Football's (FIFA) big count reported around 265 million soccer players (male and female) worldwide, which accounted for around 4 per cent of the world's population [1]. In contrast, Australian Football is a unique football code played predominantly only in Australia. It has a participation rate of estimated to be 1.2 million, however in a nation with a total population of 24 million this equates to a 5\% population participation [2]. Within Australia, many more people are also actively involved in other types of football codes, with this participation displaying regional differences.

Whatever the code, football has been found to have many positive health effects, such as significant cardiovascular and musculoskeletal adaptations, including muscle growth and elevated muscle strength [3]. Despite the beneficial effects of participating in football, there is also a high risk of injury, and this risk is particularly pronounced at the elite level, where football is a profession [4]. In professional Australian Football (i.e. the AFL) in 2015, there were 41.7 injuries per season per club resulting in missed matches [5], equating to less than 1 injury per player per season. This is comparable with the Union of European Football Associations (UEFA) injury data in which players sustained on average 2 injuries per season, however half only had short term impacts of less than one week's duration, so did not result in time lost from formal competition [6]. Hence, overall injury incidence is similar. 
The governing bodies of most professional football codes have expressed their concern about the demands being placed on footballers and the translation of these physical and mental demands into injuries [7]. Due to the high number of players involved, and the high risk of injury, the study of injury epidemiology amongst professional footballers in particular, has recently gained importance [8]. Within the AFL, the AFL Doctors Association became increasingly conscious of injury patterns and the risk to players, leading to the development of a thorough injury surveillance system at the elite level [9]. Over the ten years from 2004 to 2013 , the AFL Commission made a number of rule changes in response to injury surveillance data, eight of which were considered to have a potential impact on injuries [10]. Within professional soccer, awareness of injuries has also increased over the years and both UEFA and FIFA are concerned about the risk of injury and injury patterns $[7,8,11]$. Injuries negatively affect performance and the injury rate in professional soccer has been estimated to be approximately 1000 times higher than the overall rate for typical industrial occupations that are generally regarded to be high risk [12]. In the UEFA Champions League, the overall injury rate is around eight time-loss injuries per 1000 hours of exposure [4]. The unavailability of players to compete in UEFA soccer matches due to injury averages around 14 per cent, but varies between 5 per cent and 20 per cent [13]. In the AFL between 1992 and 2012, the seasonal incidence of injuries varied between 30.3 and 40.3 new injuries per club per season and the injury prevalence (missed matches through injury per club per season) varied from a low of 116.3 in 1994 to a high of 157.1 in 2011 [9].

\section{Why injury surveillance in football is needed}

Injury surveillance is the ongoing, routine collection and reporting of injury data [14]. Accordingly, injury surveillance is recognised as an important obligation of many professional sporting bodies around the world, with various levels of success reported [15- 
19]. The ultimate goal of injury surveillance in the professional football codes is to document and track injury occurrences so as to collect information to inform the development and implementation of strategies to increase safety in the sport $[7,20]$. There are clear medical, legal, sporting, and socio-economic arguments for carrying out injury surveillance in the professional football codes. Injury incidence can be reduced via injury prevention programmes if they are informed by high quality surveillance data. For this reason, both van Mechelen et al [21] and Finch [22] have advocated injury surveillance as the crucial first step in sports injury research.

At a national and international level, peak football bodies are legally and morally responsible for establishing minimum medical standards to protect the health and safety of players and reduce the risks associated with participation in football matches [15-19]. Injury surveillance data suggests a wide variety of measures could reduce the risk of injuries for football players; these include: changing training techniques, rule changes [10] and alterations in the medical treatment of specific injuries [10].

In addition to having a major responsibility for risk management and an overview of injury and risk patterns for football players, surveillance activities conducted at the organisational level provide a tool to evaluate injury risks and trends over time $[9,10,23]$ The National Football League (NFL) in the United States of America (USA) has the longest running football injury surveillance system (NFLISS), having maintained an injury surveillance system since the 1980s [24]. The NFL has continually used the data provided over the last 30 years to help guide its rule changes and guidelines to continually improve the safety of the game [25].

One of the first national/ international football bodies to implement routine injury surveillance in its professional players was the AFL [9]. In Australia, the AFL [5] commenced surveying injuries in 1992, with all teams and players included since 1996 [9]. It is an ongoing aim of the AFL and the AFL Doctors' Association to continually meet the standard of other 
worldwide surveillance systems such as those of UEFA, FIFA and the NFL [9]. Unlike other football surveillance systems, for example those of FIFA and the NFL, the AFL has publicly released competition injury information since 1996 [26]. A summary of the methods and results of the AFL injury survey was published in 2013 in the American Journal of Sports Medicine [9]. This was thought to be the first time a professional sports league had publicised its annual injury report in conjunction with a leading scientific sports medicine journal [26]. Furthermore, to ensure full compliance with injury surveillance, all AFL player contracts now includes consent for players' injury records to be passed from team medical staff to researchers [26].

Other football codes also recognise the importance of injury surveillance. The Elite Club Injury Study (ECIS) carried out by UEFA on teams that qualify for the group stage of the UEFA Champions League shows trends in injuries; whilst some injuries, such as ankle sprains and knee medial collateral ligament [27] injuries have decreased, the total injury risk has remained the same for 15 years of the study, in spite of all the preventive work carried out in the clubs $[28,29]$. The rate of hamstring muscle injury is even increasing year by year. One reason could be that the intensity of play has increased at the elite level, but if this is the case, it is all the more reason to intensify preventive programs and continue injury surveillance [30].

Surveillance studies at the organisational level of peak football bodies also allow the effects of changing external circumstances on injury risk to be assessed. This includes effects relating to rule changes, seasonal schedule changes, pitch surfaces and the number of teams in a competition [23]. Such studies can also provide information on how long certain injuries take to heal (ECIS database) for example, and are a useful tool for improving the exchange of information between national teams and clubs [23]. Within the AFL, the annual public release of data has led to greater public discussion about injuries and has assisted with interventions that have helped tackle the injury burden in specific areas [9]. In addition, this data has been utilised by the AFL Research Board and the AFL Doctors' Association to 
inform the conduct of additional and more detailed injury studies, such as case follow ups of certain injuries [26].

The overall aims of this narrative review are to identify and compare the ongoing injury surveillance systems employed across professional football codes from across the world. The summarised information documents current best practice in injury surveillance for these sports.

\section{EVIDENCE ACQUISITION}

The definition of injury surveillance utilised in this paper is: 'Injury surveillance is the ongoing collection of data describing the occurrence of, and factors associated with injury' [14]. Such a definition allows the monitoring of sport-related injury trends over time to demonstrate any changes in the patterns of injury [14].

Research on the injury surveillance systems implemented in professional football has been reported across a range of different sources, including websites, journal articles and reports from sporting organisations. A comprehensive and systematic search of peer reviewed and grey literature was conducted for relevant studies reporting injury surveillance in international football codes. Relevant publications were identified through systematic searches of the following electronic databases during October 2016: MEDLINE, CINAHL, Embase, Scopus, ProQuest Theses and Dissertations Global. Publications from 1980 onwards were included as this was when the National Football League Injury Surveillance System [24] commenced (thought to be the first of the football codes to introduce injury surveillance). Google Scholar was also searched for relevant publications. Search terms included 'injury surveillance', 'football', 'rugby', 'injury prevention', 'sports injury'. The terms were searched for within titles, abstracts and keywords and the search was limited to the English language. The reference lists from comprehensive reviews and identified studies were also searched. Extensive 
Google searches were conducted to find additional grey literature on identified football injury surveillance systems with no associated peer-reviewed publications, such as injury surveillance annual reports for any of the professional rugby codes. For the Google searches, search terms included the name of the surveillance system and searches of the medical information on the association's web page.

Initially the first author reviewed the titles and abstracts of the identified literature and any not meeting the criteria were excluded. All publication types were included, such as annual reports, web page information, peer-reviewed journals and theses. All professional football codes were included (Australian football, Association football, rugby union, rugby league, and American football). Gaelic football was also included as whilst it is not a professional sport, at the senior-inter county representative level, it is considered to be an elite football sport.

Studies were included if they described the methodology of ongoing injury surveillance systems in sport, that is they demonstrated at least five years of data collection and that data collection is currently on-going. Where multiple publications existed for a single surveillance system, only the most recent publications and/or publications providing the most relevant details were included.

Data were extracted for details of the surveillance system: population under surveillance, coverage (in terms of teams), years injury surveillance conducted, injury definition, who records the data, how the data is recorded, and any other relevant information, such as who the data is reported to and how the data is reported (e.g. media release, peer review journals).

\section{EVIDENCE SYNTHESIS}


A summary of the key features of the included studies is presented in Table 1 and Table 2. Table 1 states the competition, organisation, sport and country of origin and gives examples of publications that have arisen directly from injury surveillance activities. Table 2 details the methodological details of the reported surveillance systems.

Seven surveillance systems were identified that record data within various professional football codes (Soccer: $n=2$, Rugby Union: $n=1$, Australian Football: $n=1$, American Football: n=1, Rugby League: $n=1$, Gaelic Football: $n=1$ )

1. The Australian Football League's [5] annual injury report [9]

2. The National Football League's (NFL) Injury Surveillance System [31]

3. The Federation International de Football Association surveillance system $[32,33]$

4. The Union of European Football Associations (UEFA) Champions league Injury Study $[15,34]$

5. The England Professional Rugby Injury Surveillance Project (Rugby Union) [35, 36]

6. National Rugby League, Australia [37, 38]

7. Gaelic Athletic Association (GAA) Injury Database, Ireland [39-42] 
Table 1 Injury surveillance in the professional codes

\begin{tabular}{|c|c|c|c|c|}
\hline Competition/ body & Organisation & Sport/ level & Country of origin & Examples of publications \\
\hline $\begin{array}{l}\text { Australian Football league } \\
\text { annual injury survey }\end{array}$ & AFL & Australian football & Australia & $\begin{array}{l}\text { Annual public release since } 1996 \text { plus multiple } \\
\text { research journal articles }([9,18,43-47]) \text {. }\end{array}$ \\
\hline National Rugby League & NRL & Rugby League & Australia & $\begin{array}{l}\text { Internal reports published. Research journal } \\
\text { articles published }[37,38,48]\end{array}$ \\
\hline $\begin{array}{l}\text { National Football League's } \\
\text { Injury Surveillance System }\end{array}$ & NFL & $\begin{array}{l}\text { Professional American } \\
\text { Football }\end{array}$ & USA & $\begin{array}{l}\text { No annual public release but multiple arising } \\
\text { research publications over many years }[24,49- \\
54] \text {. }\end{array}$ \\
\hline $\begin{array}{l}\text { Union of European Football } \\
\text { Associations Champions League } \\
\text { Injury Study }\end{array}$ & UEFA & Soccer & $\begin{array}{l}\text { Multiple European } \\
\text { countries }\end{array}$ & $\begin{array}{l}\text { Annual reports to clubs and journal publications } \\
{[4,13,15,55,56] \text {. }}\end{array}$ \\
\hline Gaelic Football & GAA & Gaelic Football & Ireland & $\begin{array}{l}\text { National GAA Injury Database since } 2006 \text { hosted } \\
\text { at University College, Dublin. Also earlier } \\
\text { published studies [57, 58]. }\end{array}$ \\
\hline $\begin{array}{l}\text { England Professional Rugby } \\
\text { Injury Surveillance Project }\end{array}$ & RFU & Rugby Union & England & $\begin{array}{l}\text { Annual reports freely available on the internet. } \\
{[16,59-61]}\end{array}$ \\
\hline $\begin{array}{l}\text { Federation Internationale de } \\
\text { Football Association } \\
\text { surveillance system (IOC } \\
\text { approach for team sports) }\end{array}$ & FIFA & Football & Switzerland & {$[32,62]$} \\
\hline
\end{tabular}


Table $\mathbf{2}$ Methodological details of the $\mathbf{7}$ included football injury surveillance systems

\begin{tabular}{|c|c|c|c|c|c|c|c|c|}
\hline & $\begin{array}{l}\text { Football } \\
\text { code }\end{array}$ & $\begin{array}{l}\text { Organi } \\
\text { sation }\end{array}$ & $\begin{array}{l}\text { Population under } \\
\text { surveillance }\end{array}$ & Coverage & $\begin{array}{c}\text { Years injury } \\
\text { surveillance } \\
\text { conducted }\end{array}$ & Injury definition & $\begin{array}{l}\text { Who } \\
\text { records } \\
\text { data? }\end{array}$ & $\begin{array}{l}\text { How is data } \\
\text { recorded? }\end{array}$ \\
\hline $\begin{array}{l}\text { Australian Football } \\
\text { league annual } \\
\text { injury survey }\end{array}$ & $\begin{array}{l}\text { Australian } \\
\text { football }\end{array}$ & AFL & $\begin{array}{l}\text { Male, } \\
\text { professional } \\
\text { Australian } \\
\text { Football Players }\end{array}$ & $\begin{array}{l}\text { All AFL } \\
\text { teams ( } n=18 \\
\text { teams) }\end{array}$ & $\begin{array}{l}1992 \\
\text { onwards (all } \\
\text { players since } \\
1996)\end{array}$ & $\begin{array}{l}\text { Time loss (any physical or medical } \\
\text { condition that causes a player to } \\
\text { miss a match in the regular } \\
\text { season or finals) }\end{array}$ & $\begin{array}{l}\text { Team } \\
\text { medical } \\
\text { staff }\end{array}$ & $\begin{array}{l}\text { Electronic records } \\
\text { submitted to study } \\
\text { coordinator at end } \\
\text { of season. }\end{array}$ \\
\hline $\begin{array}{l}\text { National Rugby } \\
\text { League }\end{array}$ & $\begin{array}{l}\text { Rugby } \\
\text { League }\end{array}$ & NRL & $\begin{array}{l}\text { Male, } \\
\text { professional } \\
\text { Australian } \\
\text { Football Players } \\
\text { (First grade \& } \\
\text { U20s) }\end{array}$ & $\begin{array}{l}\text { All NRL } \\
\text { teams ( } n=16 \\
\text { teams) }\end{array}$ & $\begin{array}{l}\text { Internal } \\
\text { reports from } \\
2007 . \\
\text { System to be } \\
\text { updated in } \\
2017\end{array}$ & $\begin{array}{l}\text { Time loss (any physical or medical } \\
\text { condition that causes a player to } \\
\text { miss any match time in the } \\
\text { regular season or finals) }\end{array}$ & $\begin{array}{l}\text { Team } \\
\text { medical or } \\
\text { High } \\
\text { performanc } \\
\text { e staff }\end{array}$ & $\begin{array}{l}\text { Electronic records } \\
\text { submitted to study } \\
\text { coordinator at mid } \\
\text { and end of season. } \\
\text { Online surveillance } \\
\text { system for some } \\
\text { clubs }\end{array}$ \\
\hline $\begin{array}{l}\text { National Football } \\
\text { League's Injury } \\
\text { Surveillance } \\
\text { System }\end{array}$ & $\begin{array}{l}\text { Professional } \\
\text { American } \\
\text { Football }\end{array}$ & NFL & $\begin{array}{l}\text { Male, } \\
\text { professional } \\
\text { American Football } \\
\text { players }\end{array}$ & $\begin{array}{l}\text { All NFL } \\
\text { teams }(n=30 \\
\text { teams) }\end{array}$ & $\begin{array}{l}1980 \\
\text { onwards }\end{array}$ & $\begin{array}{l}\text { Time loss (any injury causing the } \\
\text { athlete to miss at least one day of } \\
\text { participation in either practices } \\
\text { or games) }\end{array}$ & $\begin{array}{l}\text { Certified } \\
\text { athletic } \\
\text { trainers }\end{array}$ & $\begin{array}{l}\text { Online surveillance } \\
\text { system }\end{array}$ \\
\hline $\begin{array}{l}\text { Union of European } \\
\text { Football } \\
\text { Associations } \\
\text { Champions League } \\
\text { Injury Study }\end{array}$ & Soccer & UEFA & $\begin{array}{l}\text { Male professional } \\
\text { soccer players } \\
\text { from top division } \\
\text { European football } \\
\text { clubs }\end{array}$ & $\begin{array}{l}46 \text { male } \\
\text { football } \\
\text { teams from } \\
10 \text { European } \\
\text { countries }\end{array}$ & $\begin{array}{l}2001 \\
\text { onwards }\end{array}$ & $\begin{array}{l}\text { Time loss (any injury occurring } \\
\text { during a scheduled training } \\
\text { session or match causing absence } \\
\text { from the next training session or } \\
\text { match) }\end{array}$ & $\begin{array}{l}\text { Team } \\
\text { medical } \\
\text { staff }\end{array}$ & $\begin{array}{l}\text { Online surveillance } \\
\text { system }\end{array}$ \\
\hline Gaelic Football & $\begin{array}{l}\text { Gaelic } \\
\text { Football }\end{array}$ & GAA & $\begin{array}{l}\text { Male GAA players } \\
\text { from the senior } \\
\text { Inter-County } \\
\text { playing } \\
\text { population }\end{array}$ & $\begin{array}{l}45 \text { football } \\
\text { teams (and } \\
32 \text { hurling } \\
\text { teams) }\end{array}$ & $\begin{array}{l}2006 \\
\text { onwards }\end{array}$ & $\begin{array}{l}\text { Time loss - 'any injury that } \\
\text { prevents a player from taking a } \\
\text { full part in all training and match } \\
\text { play activities typically planned } \\
\text { for that day, where the injury has } \\
\text { been there for a period greater } \\
\text { than } 24 \mathrm{~h} \text { from midnight at the } \\
\text { end of the day that the injury was } \\
\text { sustained'. }\end{array}$ & $\begin{array}{l}\text { Team } \\
\text { physiothera } \\
\text { pists or } \\
\text { doctors } \\
\text { submit } \\
\text { weekly } \\
\text { information } \\
\text { from } \\
\text { matches or } \\
\text { training } \\
\text { sessions } \\
\end{array}$ & $\begin{array}{l}\text { Online surveillance } \\
\text { system }\end{array}$ \\
\hline
\end{tabular}




\begin{tabular}{|c|c|c|c|c|c|c|c|c|}
\hline $\begin{array}{l}\text { England } \\
\text { Professional Rugby } \\
\text { Injury Surveillance } \\
\text { Project }\end{array}$ & Rugby Union & RFU & $\begin{array}{l}\text { Male professional } \\
\text { rugby union } \\
\text { players }\end{array}$ & $\begin{array}{l}\text { All } \\
\text { Premiership } \\
\text { Clubs ( } n=12 \\
\text { clubs) }\end{array}$ & $\begin{array}{l}2002 \\
\text { onwards }\end{array}$ & $\begin{array}{l}\text { Time loss and medical attention } \\
\text { (any injury (1) resulting from } \\
\text { participation in an organised high } \\
\text { school athletic practice or } \\
\text { competition, (2) requiring } \\
\text { medical attention from an } \\
\text { athletic trainer or a physician, (3) } \\
\text { restricting the athlete's } \\
\text { participation for one or more } \\
\text { days beyond the day or injury, } \\
\text { and (4) any fracture, concussion } \\
\text { or dental injury) }\end{array}$ & $\begin{array}{l}\text { Certified } \\
\text { athletic } \\
\text { trainers }\end{array}$ & $\begin{array}{l}\text { Online surveillance } \\
\text { system }\end{array}$ \\
\hline $\begin{array}{l}\text { Federation } \\
\text { Internationale de } \\
\text { Football } \\
\text { Association } \\
\text { surveillance system } \\
\text { (IOC approach for } \\
\text { team sports) }\end{array}$ & Soccer & FIFA & $\begin{array}{l}\text { Male and female, } \\
\text { professional } \\
\text { football players } \\
\text { participating in all } \\
\text { FIFA } \\
\text { competitions. }\end{array}$ & $\begin{array}{l}\text { Not } \\
\text { reported, } \\
\text { likely } \\
\text { convenience } \\
\text { sample }\end{array}$ & $\begin{array}{l}1998 \\
\text { onwards } \\
\text { (started with } \\
1998 \text { FIFA } \\
\text { World Cup) }\end{array}$ & $\begin{array}{l}\text { All match injuries (any physical } \\
\text { complaint arising during the } \\
\text { match regardless of the } \\
\text { consequences with respect to } \\
\text { subsequent absence from } \\
\text { matches or training. }\end{array}$ & $\begin{array}{l}\text { Team } \\
\text { physicians }\end{array}$ & $\begin{array}{l}\text { Paper-based forms } \\
\text { completed after } \\
\text { each match and } \\
\text { collected by a FIFA } \\
\text { representative }\end{array}$ \\
\hline
\end{tabular}


A number of national and international football 'organisations' were excluded from the review for a variety of different reasons. Whilst some organisations are known to have an existing injury surveillance system, we were unable to access any of the required information for the review either because no peer review papers have been written from the findings; the findings are not disclosed to the media; or the findings were not publicly disseminated. It appears the findings from these surveillance systems are only fed back directly to the clubs and players. Other excluded football injury surveillance systems related to the amateur or recreational or non-professional levels of the sport only (e.g. junior, Olympic, US College).

Some football federations have reporting guidelines in place for particular injuries, such as concussion, and have official reporting procedures for catastrophic and fatal injuries, which include for example, spinal cord injuries, brain injuries and fatalities. However, they may not have an injury surveillance system in place for other injuries and so have not been included in this review.

A number of professional football codes have previously published their findings from injury surveillance. However, on review, it appears that the surveillance had only been carried out a) for a specified length of time (e.g. for one tournament, or over one season); b) on a convenience or stratified sample of the population, such as a specified number of teams in the competition; c) data collection was not current; or d) was not performed uniformly for all players and teams in a competition.

Of the seven identified systems discussed in this review, one of the systems included data for both male and female football players [33], while the remaining six collect data on male football players only $[4,9,15,38,41,49,59]$. None of the surveillance systems were devoted solely to females. Four of the surveillance systems are based in Europe $[4,41,56$, 59], one in the United States [49] and two in Australia [9, 38]. All of the reviewed systems operate as censuses; that is, they capture data from all clubs, teams and athletes within their target population. The seven included systems have been operating for between 9 and 30 
years. Established in 1980, the National Football League's system is the longest running [31].

The surveillance system methods are presented in Table 2. Five systems employ injury definitions relating to time loss from participation in sport $[9,37,38,41,49,63]$. One system utilises injury definitions incorporating both time loss and medical attention [36, 64], while the remaining system includes all injuries [33].

Team doctors or physiotherapists are responsible for recording injury data in five systems [9, $33,37,38,41,63]$. For two systems, certified athletic trainers record data $[36,49,64]$. No systems used non-medically trained technical personnel to complete the injury report forms.

Four of the systems utilise online forms enabling injury details to be directly uploaded to a central database $[36,41,49,63,64]$; one system utilises paper-based forms that are completed after each match and collected by a representative [33]. One system incorporates an electronic form or spread sheet that is submitted to the study coordinator at the end of each season [9]. The remaining system uses either electronic records or, where available for some clubs, an online surveillance system $[37,38]$.

All of the reviewed systems have published multiple research journal articles from their results. One of the systems releases their data annually to the press [9]. For one of the systems, the annual report is freely available to the press and general public on the internet $[36,64]$. Other systems produce internal reports that are disseminated to all clubs.

\section{CONCLUSIONS}

A range of methods and approaches were used across the football surveillance systems with variations in the definition of injury, the type of personnel recruited for recording data, the tool used for recording injury details, how the data were disseminated and who the data 
were disseminated to. Nevertheless, there were similarities across the football codes and many of the surveillance systems comply with relevant consensus statements $[16,17]$ where they exist.

There are numerous benefits for football clubs in conducting comprehensive injury surveillance. Their primary consideration is to provide important information to support player performance that enables them to win games and therefore intuitively, minimising injuries is important to help achieve this goal. Depletion of playing staff due to injuries has been shown to have a clear impact on the overall success of a team, and elite teams with less injured players achieve better results and higher championship rankings [63]. Having an injury free team enables coaches to have the most complete squad possible available for training, allowing them to select their best squad for matches [30]. In turn, this ensures the team is able to perform to its full potential [65].

The findings from injury surveillance are valuable for football clubs because they can be used to evaluate injury trends over time and study the effects of changing external circumstances on injury risk such as change of coaches, change of training programmes and for tactical performance purposes [30]. Injury surveillance is also the first step in a professional club's risk management strategy and provides direct feedback of the injury situation at their club, allowing comparison with other clubs [23].

There is a clear financial incentive for football clubs to reduce injuries and manage injury risk. For example in soccer, a player at a Champions league-level club costs their club around Euros 600, 000 per month of injury [66]. The total number of injury days ranges from 200 to 1500 per year per club [66] and it has been estimated that the average cost to a club due to injuries is around Euros 20 million a season [30]. Therefore, by carrying out injury studies and providing evidence that helps design and implement strategies to prevent injuries, injury surveillance can also help clubs to improve their finances [23]. 
For players, staying injury free is the only way for them to perform to their full potential [65]. Injury surveillance data therefore also provides important information to players about the risk of injury in their profession and information about how to avoid injuries [30]. Furthermore, injury prevention programmes may play a role in enhancing performance [67].

\section{Comparison between codes -differing definitions of injury and therefore injury rates}

Appreciation of the benefits of injury surveillance in professional football for football federations, clubs and players themselves, necessitates an evidence base to guide surveillance methods, and inform policy and practice across the different football codes. However, there is no methodological consensus for epidemiological studies on injuries across the various football codes and therefore, meaningful comparisons of exposure and injury epidemiology, can often not be drawn [7]. Further, differences in injury definitions and the varying nature of demands of football competitions make it difficult to compare the injury rates in different codes [46]. Previously, only reports from emergency departments and insurance claims were utilised to profile injuries sustained in specific sports [8]. However, these reports have many limitations in that they only include a relatively small proportion of

the injuries that occur and only serious injuries are usually recorded [8]. In addition, hospital data tend to focus on injury outcomes rather than investigation into their causes. In order to capture a broader range of injuries than those reported in more routine hospital data sets, many football codes have elected to use a much broader definition of injury, which is inclusive of more minor injuries that prevent a player being able to fully participate in training or match play [46].

\section{Time loss and other injury definitions}


Five systems reviewed use time loss as the unit of measurement for definition of injuries. For example, the AFL reports injury rates as seasonal injury incidence, that is, the number of 'missed matches/ new injuries per club per season' [18]. The definition is linked to injury incidence but includes an additional unit, injury severity, which is the average number of matches missed per injury [18]. The injury recurrence rate is the number of recurrent injuries expressed as a percentage of the number of new injuries and is classed as an injury within the same injury category occurring on the same side of the body in a player during the same season $[9,18]$.

In an era before computerised recording and professional medical staff, this definition gave a reliable system that allowed comparison of data across different seasons, allowed every team to be included and promoted consistency across all AFL clubs. Other sports that surveyed 'all' injuries had poorer rates of compliance and therefore the process became derailed. A time loss injury definition, such as that used in the AFL, meant that the professional club doctors could achieve and deliver full compliance with reporting against it, and therefore it promoted consistency $[18,68]$. Seasonal incidence is a measure that is also easily understood by the layperson (non-medical AFL club staff, coaches and list managers), and the AFL's annual public release of injury rates, made this choice of units preferable [18, 68]. A layperson for example can understand that a club will experience six hamstring injuries per season on average, but reading that the rate is eight injuries per 1000 players hours does not give the same sense of how common these injuries are [46].

At times this definition of injury, as used by the AFL, has been criticised as other sports, such as the NRL, measure injury incidence as the number of injuries per 1000 player hours or per 1000 athlete exposures [49]. In addition, the time loss injury definition attracts some criticism, as it does not include the entire spectrum of injuries [9]. A time loss definition excludes those players who require pain relief, including local anaesthetic injections, in order to continue playing but who do not miss a match [69]. Players who receive treatment for an injury between games but who do not also miss playing time are not captured by a time loss 
definitions. Finally, time loss definitions do not include those injuries where a player can continue to play during a season but may require surgery and rehabilitation after a season ends [69]. Injury surveillance reports that separate match and training injuries and express the incidence of these in number of injuries per 1000 player hours, have also been criticised as it can be difficult to characterise some injuries, such as overuse injuries, as solely being a 'match' or a 'training' injury [70].

Both, injury incidence (total of injuries per 1000 hours) and time loss of injuries have more recently been criticised as they do not provide any information on the accumulation of other injuries that might have preceded an injury or also occurred in injured persons $[66,71]$. It is argued that without the pre-injury data, clubs may find it more difficult to identify patterns associated with injury and therefore apply them in their injury prevention strategies $[66,72]$. Furthermore, neither definition gives an indication of the intensity and load placed on players during the hours of game play or training [66]. In addition, an injured player is considered 'fully fit' when they return to full participation. Exacerbations of unresolved injuries may then be counted as a re-injury and therefore be recorded as a new injury; this results in a higher incidence of injury [66]. The AFL and the AFL Doctors Association recognise that the injury surveillance provided by their annual report is not comprehensive enough to provide more comprehensive injury data with respect to conditions like concussion, which may have longer term implications than just the short term consideration of missing games [26]. The AFL is therefore funding further studies particularly researching conditions such as concussion, in further detail [26]

There is a need and an ability to extend data collection beyond the core element of injuries that cause missed games. For example, the FIFA injury definition includes all newly incurred football injuries during the FIFA tournaments and the Olympic Games [33]. It includes any match injuries (any physical complaint including concussion) arising during the match that received medical attention from the team physician, regardless of the consequences with respect to subsequent absence from matches or training [33]. However, to fully understand 
player injuries, surveillance systems would benefit from insights into player performance and the role of injury, such as the ability to track GPS, player wellness, match performance or other data associated with the player's injury [66]. Whilst GPS monitoring of player movement patterns is widespread in the AFL and the AFL publishes this data and its links with performance, documented analysis and relation to player injury is lacking [73]. Players' medical, physiological, training and match data has implications for game authorities, players and coaching staff [73], and could be combined to provide valuable insights into players' recovery and risk profile [66].

The NFL has traditionally had a time-loss definition of injury but with concussion as an exception (that is, any concussion is included in the injury surveillance system even if it did not cause any time-loss). Concussion has emerged in surveillance systems, as the type of injury that does require special treatment as it is now recognised that non-time-loss concussions could potentially have long-term consequences for players. However, it is problematic to have a different reporting definition or threshold for concussion than for other injuries. A "medical presentation" definition for concussion, whilst broader and traditionally capturing more events than a "time loss" definition, still is problematic with respect to recording all potentially important head injury events. In particular, now that most football codes insist on exclusion of concussed players from the remainder of the game, there is the potential that players could hide concussion symptoms from the medical staff. It is quite likely that the future obligations of professional football codes will include development of a separate "head impact" registry that records all details of documented events (whether presenting in the traditional clinical sense, or alternatively via video replay assessment/ spotters, or even accelerometer data).

Finally, where definitions of injury are similar across football codes, it may still be difficult to compare injury rates. For example, in the European soccer competitions it is commonplace for teams to play two matches per week and for players to be rested from the second match 
with minor conditions [46]. Whereas in the AFL, NRL and NFL, with one match per team per week, there is less likelihood of this occurring [46].

\section{Consensus statements}

Guidance on key issues relating to injury surveillance in specific sports, including how to define an injury and which injury details to collect, has traditionally been provided through consensus statements [17]. Consensus statements on injury definitions and procedures for injury surveillance in sports such as cricket and association football, have demonstrated the benefits gained from the use of common definitions and methodologies [17]. It is believed that data gained from describing an injury according to a standardised methodology will increase the current knowledge base in the area, in addition to reducing injuries [74]. The FIFA Medical Assessment and Research Centre devised a consensus statement for association football in order to standardise definitions, methodology, implementation and reporting standards that should be adopted for football injuries [17]. The statement provides a minimum standard for transparency and reliability in sports injury research using the Orchard Sports Injury Classification System (OSICS) [17]. An injury is defined as, 'Any physical complaint sustained by a player that results from a football match or football training, irrespective of the need for medical attention or time loss from football activities' [17]. The consensus statement for association football, in addition to the definition for injury, provides definitions for medical attention injury, time loss injury, recurrent injury, injury severity, match exposure and training exposure. It terms of methodology, it states that studies should be of a prospective cohort design to minimise recall bias, and data should be collected on standardised electric or paper forms [17].

The consensus statement developed by the FIFA Medical Assessment and Research Centre (F-MARC), showed similarities with definitions and methodologies used in peerreviewed publications of studies of rugby union and therefore the International Rugby Board 
used the football consensus statement to develop a consensus statement for rugby union [16]. Whilst some changes were required because of the inherent differences between rugby union and football, the football consensus statement forms an integral part of the rugby union consensus statement [16]. There are no current injury surveillance consensus statements for other professional football codes.

\section{Dissemination of findings}

In Australia, the AFL practises open disclosure of its surveillance findings and reports injury rates to the media annually. There have been many benefits to this decision: development of the profile of the AFL Doctors' Association, promotion of the AFL as a world leader in sports science and medicine, and demonstration of successful injury prevention in the AFL competition [9]. Furthermore, public knowledge of an increasing injury burden in a certain area tends to mean there is greater acceptance of any recommended rule changes [9]. Obligatory public disclosure of injury data for all professional sports could assist in reducing the burden of injury [9].

Whilst the NFL Injury surveillance system has been in place since the 1980s, it does not publicly release its data on an annual basis, although multiple studies on the data have been published in the scientific literature $[49,50,52,53]$. IN 1994, F-MARC started in order to create and disseminate scientific knowledge on various medical topics in football, including reducing football injuries [75]. FIFA also do not specifically publicly release their data but they have over 50 publications in peer-reviewed journals and this work is continuing internationally [75]. UEFA has the world's largest database on elite level football injuries and the knowledge from UEFA's Football Research Group ongoing survey has resulted in over 40 articles in peer-reviewed scientific journals [23]. 
In the AFL, there has generally been positive reporting from the media of these disclosures. However more recently, the ongoing value of this has been questioned. Whereas previously the media were often grateful to have been given data to run as a story annually, more recently there has been an evolution of media attitude to a stance that the widely disseminated injury data does not demonstrate full disclosure. Where there are injuries that are not fully understood, there is an implication that these areas are being covered up (as opposed to being attempted to be understood). With significant sections of the media positioning themselves as not being trustful of any injury data that gets released, the goodwill of releasing data has diminished. Many other professional sports have joined the AFL in injury surveillance, research publications and a funded research board but it is telling that others have not tended to go down the public release route. It is possible that other professional football codes also consider there to be a risk in the media painting the sport in a negative light for drawing attention to injury data.

\section{Financial considerations}

One of the keys to successful injury surveillance in different sports is funding from the international and national sports organisations [23]. Funding is a crucial factor in the process of building up and maintaining a database and register [76]. Guaranteed funding for a period of time favours retention of good quality staff and permits quality control [76]. The predominance of surveillance systems within popular (and well-resourced) spectator sports, such as football, likely reflects the fact that successful injury surveillance systems rely on significant financial and operation resources for their continued operation [76, 77]. To maintain consistent standards of practice over long periods of time, ongoing funding or the cooperation of sporting organisations is required [76]. Furthermore, factors such as significant financial and operational resources, are likely to influence the level of cooperation at the club level amongst players, coaches and medical staff, as evidenced by the high 
number of professional leagues able to conduct a complete census of their target population, [78].

\section{Practical implications of injury survey data}

Identification of common injuries and injury patterns in football injury surveillance is utilised to identify causative factors, develop preventative programmes and, where required, implement rule changes [41]. For example, in the AFL, the centre circle rule introduced in 2005, successfully led to a reduction in PCL injuries in ruckmen [46]. Rates of hamstring and groin injuries have significantly fallen since the substitute rule was introduced in 2011 [10]. The substitute rule and concussion rule in AFL (the player must not return to play or training on the day of injury) have both enabled concussion management to be improved and alleviates pressure on players to downplay concussion symptoms [26]. In the NFL, forty two rule changes have been made since 2002 to protect players [25]. For example, changes to the kickoff rules have lowered the number of concussions sustained during kickoffs and the NFL will continue to track the data and study further options that may result in safer play [25].

Long-term injury surveillance has allowed some comparison between football codes and findings have demonstrated that football codes with a greater number of tackles, tend to have higher rates of contact mechanism injuries. Unsurprisingly, football codes that have less tackling and more free running, tend to report more running-related non-contact injuries [46].

Another major outcome of the investment in surveillance systems such as the AFL Annual Injury Survey, has been the development and refining of the Orchard Sports Injury Classification System (OSICS). The OSICS was developed in 1992 for use in the incidence of injury at the elite level of AFL, rugby league and rugby union in Australia and is the 
primary coding system for AFL [18] and Cricket Australia [79]. It is now regarded internationally as one of the most common systems for coding injury diagnosis in sports injury surveillance systems [80]. The OSICS is commonly used in the sports of association football, Australian football, rugby union, cricket and tennis and its major strengths are that it has wide usage and is free to use [80].

None of the injury surveillance systems included in this review extended surveillance into the retirement years of a player. Such an extension would be extremely costly and logistically difficult, as contracts between a professional player and a sport typically end at the time of, or shortly after, retirement.

\section{Limitations}

There are some limitations affecting the outcomes of this review. The review of footballing injury surveillance systems is limited by what we could find that was published in electronic form. This review therefore contains no information on relating to injury surveillance systems used by professional sports bodies if the data has not been published. Despite the extensive search, it is possible that relevant injury surveillance systems may have been missed, as some of the literature can be difficult to locate. If this were the case, this paper would be an under-representation of injury surveillance activities globally at the professional/ elite level of football. In addition, it was difficult to compare the surveillance systems of onecountry national federations, for example, the AFL, with major international governing bodies such as FIFA, UEFA and the NFL due to differences in resources, such as financial and technology.

\section{CONCLUDING REMARKS}


This review has identified a number of existing injury surveillance systems within elite and professional football codes. All professional sporting competitions face the ongoing challenge of delivering a free-flowing, continuous and entertaining spectacle while trying to keep players free from injury [26]. Football codes that have funded and supported sportsspecific research that aims to improve our knowledge of how to keep athletes in good health, have made an important impact in sports medicine research. The findings of football injury surveillance systems demonstrate unequivocally that appropriate sports injury prevention research can lead to the implementation of interventions that make football safer [23]. Ongoing injury surveillance in elite football allows both identification of areas for further research and monitoring of the effect of interventions. Within the AFL it is claimed that public annual release of injury data has contributed to greater acceptance of changes within the game and successful injury prevention [26]. Finally, whilst consensus statements provide a useful framework for injury reporting, surveillance methodologies must be appropriate to both the sport and the specific context in which the surveillance takes place [17]. 


\section{REFERENCES}

1. FIFA, FIFA big count 2006. 2007.

2. Australian Football League, Australian Football League Annual Report 2015. 2015.

3. Krustrup, P., et al., Executive summary: The health and fitness benefits of regular participation in small-sided football games. Scandinavian journal of medicine \& science in sports, 2010. 20(s1): p. 132-135.

4. Bengtsson, H., J. Ekstrand, and M. Hägglund, Muscle injury rates in professional football increase with fixture congestion: an 11-year follow-up of the UEFA Champions League injury study. British Journal of Sports Medicine, 2013. 47(12): p. 743-747.

5. AFL Doctors Association, AFL Physiotherapists Association, and AFL Football Operations Department, 2015 AFL Injury Survey. 2015.

6. Ekstrand, J., M. Hägglund, and M. Waldén, Injury incidence and injury patterns in professional football: the UEFA injury study. British Journal of Sports Medicine, 2011. 45(7): p. 553-558.

7. Ekstrand, J. and J. Karlsson, Editorial. Scandinavian Journal of Medicine \& Science in Sports, 2003. 13(3): p. 147-149.

8. Eirale, C., Epidemiology in professional footballers, in Football Traumatology, P. Volpi, Editor. 2015, Springer International Publishing, Switzerland.

9. Orchard, J.W., H. Seward, and J.J. Orchard, Results of 2 Decades of Injury Surveillance and Public Release of Data in the Australian Football League. The American Journal of Sports Medicine, 2013. 41(4): p. 734-741.

10. Orchard, J., et al., Use of rule changes to reduce injury in the Australian Football League. Minerva Ortopedica E Traumatologica, 2014. 65(6): p. 355-64.

11. D'Hooghe, M., Why is UEFA carrying out injury studies? British Journal of Sports Medicine, 2016. 50(12): p. 707.

12. Drawer, S. and C.W. Fuller, Evaluating the level of injury in English professional football using a risk based assessment process. British Journal of Sports Medicine, 2002. 36(6): p. 446-451.

13. Ekstrand, J., et al., Fewer ligament injuries but no preventive effect on muscle injuries and severe injuries: an 11-year follow-up of the UEFA Champions League injury study. British Journal of Sports Medicine, 2013. 47(12): p. 732-737.

14. Finch, C.F., An overview of some definitional issues for sports injury surveillance. Sports medicine, 1997. 24(3): p. 157-163.

15. Hägglund, M., et al., Methods for epidemiological study of injuries to professional football players: developing the UEFA model. British Journal of Sports Medicine, 2005. 39(6): p. 340346.

16. Fuller, C.W., et al., Consensus Statement on Injury Definitions and Data Collection Procedures for Studies of Injuries in Rugby Union. Clinical Journal of Sport Medicine, 2007. 17(3): p. 177181.

17. Fuller, C.W., et al., Consensus statement on injury definitions and data collection procedures in studies of football (soccer) injuries. British Journal of Sports Medicine, 2006. 40(3): p. 193201.

18. Orchard, J. and H. Seward, Epidemiology of injuries in the Australian Football League, seasons 1997-2000. British Journal of Sports Medicine, 2002. 36(1): p. 39-44.

19. Thacker, S.B., Editorial: Public Health Surveillance and the Prevention of Injuries in Sports: What Gets Measured Gets Done. Journal of Athletic Training, 2007. 42(2): p. 171-172.

20. Finch, C.F., et al., Priorities for Investment in Injury Prevention in Community Australian Football. Clinical Journal of Sport Medicine, 2013. 23(6): p. 430-438.

21. van Mechelen, W., Sports injury surveillance systems. Sports medicine, 1997. 24(3): p. 164168. 
22. Finch, C., A new framework for research leading to sports injury prevention. Journal of Science and Medicine in Sport, 2006. 9(1): p. 3-9.

23. Ekstrand, J., J. Dvorak, and M. D'Hooghe, Sport medicine research needs funding: the International football federations are leading the way. British Journal of Sports Medicine, 2013. 47(12): p. 726-728.

24. Powell, J.W. and M. Schootman, A multivariate risk analysis of selected playing surfaces in the National Football League: 1980 to 1989: An epidemiologic study of knee injuries. The American Journal of Sports Medicine, 1992. 20(6): p. 686-694.

25. National Football League, Play Smart, Play Safe. 2016.

26. Orchard, J.H., H. Seward, and J. Orchard, 2014 AFL Injury Report. 2014.

27. Whitehouse, T., et al., The epidemiology of injuries in Australian professional rugby union 2014 Super Rugby competition. Orthopaedic journal of sports medicine, 2016. 4(3): p. 2325967116634075.

28. Lundblad, M., et al., The UEFA injury study: 11-year data concerning $346 \mathrm{MCL}$ injuries and time to return to play. British Journal of Sports Medicine, 2013. 47(12): p. 759-762.

29. Waldén, M., M. Hägglund, and J. Ekstrand, Time-trends and circumstances surrounding ankle injuries in men's professional football: an 11-year follow-up of the UEFA Champions League injury study. British Journal of Sports Medicine, 2013. 47(12): p. 748-753.

30. Ekstrand, J., Preventing injuries in professional football: thinking bigger and working together. British journal of sports medicine, 2016. 50(12): p. 709-710.

31. Henderson, L., Injury surveillance system kickoff., A.C.T. Online., Editor. 2012.

32. Junge, A., et al., Football Injuries During FIFA Tournaments and the Olympic Games, 19982001: Development and Implementation of an Injury-Reporting System. The American Journal of Sports Medicine, 2004. 32(1 suppl): p. 80S-89S.

33. Junge, A. and J. Dvorak, Injury surveillance in the world football tournaments 1998-2012. British journal of sports medicine, 2013: p. bjsports-2013-092205.

34. The Football Research Group. The Football Research Group, Linkoping. 2016 6th October 2016.]; Available from: http://www.footballresearchgroup.eu.

35. Group, F.R. 2016 29th Nov 2016]; Available from: http://www.footballresearchgroup.eu.

36. Rugby Football Union. England Professional Rugby Injury Surveillance Project : 2013-2014 Season Report. 2015 6th October 2016]; Available from: http://www.englandrugby.com/mm/Document/General/General/01/30/80/08/EnglandProf essionalRugbylnjurySurveillanceProjectReport2013 2014 Neutral.pdf.

37. O'Connor, D., NRL injury report 2010. Sport Health, 2011. 29(1): p. 17.

38. O'Connor, D., NRL injury report 2011. Sport Health, 2012. 30(1): p. 12.

39. Blake, C., et al., INJURY TO THE HEAD REGION IN ELITE MALE GAELIC FOOTBALL AND HURLING: 2007-2012. British Journal of Sports Medicine, 2014. 48(7): p. 569.

40. Blake, C., et al., A prospective study of injury in elite gaelic games. British Journal of Sports Medicine, 2011. 45(4): p. 337.

41. Murphy, J.C., et al., Incidence of Injury in Gaelic Football: A 4-Year Prospective Study. The American Journal of Sports Medicine, 2012. 40(9): p. 2113-2120.

42. Roe, M., et al., Hamstring injuries in elite Gaelic football: an 8-year investigation to identify injury rates, time-loss patterns and players at increased risk. British Journal of Sports Medicine, 2016.

43. Seward, H. and J. Orchard, AFL injury report 2002. Sport Health, 2003. 21(2): p. 18.

44. Seward, H. and J. Orchard, AFL injury report 2003. Sport Health, 2004. 22(2): p. 7.

45. Orchard, J. and G.M. Verrall, Groin Injuries in the Australian Football League. International SportMed Journal, 2000. 1(1).

46. Orchard, J. and H. Seward, Comparing AFL injury surveilance to other codes. Sport Health, 2009. 27(2): p. 38-41.

47. Orchard, J. and H. Seward, AFL injury report. Sport Health, 2006. 24(3): p. 15. 
48. O'Connor, D. A prospective study of injuries sustained during a National Rugby League season. in Science and Football VII: The Proceedings of the Seventh World Congress on Science and Football. 2013. Routledge.

49. Feeley, B.T., et al., Hip Injuries and Labral Tears in the National Football League. The American Journal of Sports Medicine, 2008. 36(11): p. 2187-2195.

50. Carey, J.L., et al., Outcomes of anterior cruciate ligament injuries to running backs and wide receivers in the National Football League. The American journal of sports medicine, 2006. 34(12): p. 1911-1917.

51. Orchard, J.W. and J.W. Powell, Risk of Knee and Ankle Sprains under Various Weather Conditions in American Football. Medicine \& Science in Sports \& Exercise, 2003. 35(7): p. 1118-1123.

52. Mall, N.A., et al., Upper extremity injuries in the national football league part l: hand and digital injuries. The American journal of sports medicine, 2008. 36(10): p. 1938-1944.

53. Carlisle, J.C., et al., Upper extremity injuries in the national football league part II: Elbow, forearm, and wrist injuries. The American journal of sports medicine, 2008. 36(10): p. 19451952.

54. Torg, J.S., et al., The National Football Head and Neck Injury Registry: 14-year report on cervical quadriplegia, 1971 through 1984. Jama, 1985. 254(24): p. 3439-3443.

55. Werner, J., et al., UEFA injury study: a prospective study of hip and groin injuries in professional football over seven consecutive seasons. British Journal of Sports Medicine, 2009. 43(13): p. 1036-1040.

56. Hägglund, M., M. Waldén, and J. Ekstrand, UEFA injury study-an injury audit at European Championships 2006 to 2008. British journal of sports medicine, 2009.

57. Wilson, F., et al., A 6-month prospective study of injury in Gaelic football. British Journal of Sports Medicine, 2007. 41(5): p. 317-321.

58. Cromwell, F., J. Walsh, and J. Gormley, A pilot study examining injuries in elite gaelic footballers. British Journal of Sports Medicine, 2000. 34(2): p. 104-108.

59. Brooks, J.H.M., et al., Epidemiology of injuries in English professional rugby union: part 1 match injuries. British Journal of Sports Medicine, 2005. 39(10): p. 757-766.

60. Brooks, J.H.M., et al., Epidemiology of injuries in English professional rugby union: part 2 training Injuries. British Journal of Sports Medicine, 2005. 39(10): p. 767-775.

61. Rugby Football Union. England Professional Rugby Injury Surveillance Project : 2013-2014 Season Report. 2015 6th October 2016]; Available from: http://www.englandrugby.com/mm/Document/General/General/01/30/80/08/EnglandProf essionalRugbylnjurySurveillanceProjectReport2013 2014 Neutral.pdf.

62. Junge, A., J. Dvorak, and T. Graf-Baumann, Football Injuries During the World Cup 2002. The American Journal of Sports Medicine, 2004. 32(1 suppl): p. 23S-27S.

63. Hägglund, M., et al., Injuries affect team performance negatively in professional football: an 11-year follow-up of the UEFA Champions League injury study. British Journal of Sports Medicine, 2013. 47(12): p. 738-742.

64. Rugby Football Union, England Professional Rugby Injury Surveillance Project 2014-15 Season Report. 2016.

65. Bizzini, M. and J. Dvorak, Football Injury Prevention, in Football Traumatology. 2015, Springer. p. 35-46.

66. Heslop, L. Injury analytics and the power of data. 2015 29th Nov 2016]; Available from: http://www.globalsportsjobs.com/article/prozone-performance-lab-injury-analytics/.

67. Bizzini, M., A. Junge, and J. Dvorak, Implementation of the FIFA 11+ football warm up program: How to approach and convince the Football associations to invest in prevention. British Journal of Sports Medicine, 2013. 47(12): p. 803-806. 
68. Orchard, J.M.D.P. and W.M.C. Hoskins, For Debate: Consensus Injury Definitions in Team Sports Should Focus on Missed Playing Time. Clinical Journal of Sport Medicine, 2007. 17(3): p. 192-196.

69. Orchard, J., H. Seward, and W. Hoskins, Epidemiology and injury in surveillance in sports medicine., in Sports Injuries, M. Hutson and C. Speed, Editors. 2011, Oxford University Press.

70. Timpka, T., et al., What is a sports injury? Sports medicine, 2014. 44(4): p. 423-428.

71. Fortington, L.V., et al., Reporting multiple individual injuries in studies of team ball sports: a systematic review of current practice. Sports medicine, 2016: p. 1-20.

72. Finch, C.F., et al., A new way of categorising recurrent, repeat and multiple sports injuries for injury incidence studies-the subsequent injury categorisation (SIC) model. Australasian Epidemiologist, 2015. 22(1): p. 22.

73. Wisbey, B., et al., Quantifying movement demands of AFL football using GPS tracking. Journal of Science and Medicine in Sport. 13(5): p. 531-536.

74. Renshaw, A. and P.C. Goodwin, Injury incidence in a Premier League youth soccer academy using the consensus statement: a prospective cohort study. BMJ Open Sport \& Exercise Medicine, 2016. 2(1).

75. FIFA Medical Assessment and Research Centre. Research and development F-MARC. 2016 5th Dec 2016]; Available from: http://f-marc.com/about-us/.

76. Orchard, J.W., Injury surveillance in cricket. Br J Sports Med, 2013. 47(10): p. 605-6.

77. Holder, Y., et al., Injury surveillance guidelines. 2001: World Health Organization.

78. Ekegren, C.L., B.J. Gabbe, and C.F. Finch, Sports Injury Surveillance Systems: A Review of Methods and Data Quality. Sports Med, 2016. 46(1): p. 49-65.

79. Orchard, J., et al., Methods for injury surveillance in international cricket. Journal of Science and Medicine in Sport, 2005. 8(1): p. 1-14.

80. Orchard, J. The Orchard Sports Injury Classification System (OSICS). 2016 29th Nov 2016]; Available from: http://www.johnorchard.com/about-osics.html. 